\title{
Students' Readiness for Self Directed Learning and its Relation to their Perception of Learning Context in Alexandria and Damanhour Nursing
}

\section{Faculties}

\author{
Abeer Abd El Fattah Abou Shousha, Lecturer \\ Nursing Education, Faculty of Nursing, Damanhour University \\ Hanan Hosni El Sherbini, Lecturer \\ Community Health Nursing, Faculty of Nursing, Alexandria University
}

\begin{abstract}
Self-directed learning (SDL) has become a focus for nursing education in the past few decades due to the complexity and changes in nursing profession development. Objective: The aim of the present study was to assess community health nursing students' readiness for selfdirected learning and identify its relation to their perception of the learning context in Alexandria and Damanhour Nursing Faculties. Setting: The study was conducted at two Faculties of Nursing, Alexandria \& Damanhour. Subjects: Using the equal allocation method, a convenient sample of 100 undergraduate nursing students registered at the Community Health Nursing Course during the second semester of the academic year 20132014 were selected from each of the previously mentioned settings $(n=200)$. Tools: Three tools were used for data collection. The first tool was students' basic data structured questionnaire to identify the students' personal and academic data. The second was Selfdirected Learning Readiness Scale (SDLRS) for nurses to assess the students' readiness for self-directed learning. However, the third tool was Course Experience Questionnaire (CEQ) to assess the students' perception of the learning context. Results: Readiness for self-directed learning among students in Alexandria Faculty of Nursing was significantly higher than those in Damanhour Nursing Faculty and that students' readiness for self-directed learning is significantly affected by their perception of the learning context in both Faculties. Conclusion: Students' readiness for self-direction in learning was significantly affected by their academic performance and studying hours in both faculties. Students' perception of the learning context had a significant positive correlation with their self-directed learning abilities. Recommendations: Assessing nursing students' readiness for self-directed learning and incorporating independent learning strategies in the nursing curricula.
\end{abstract}

Keywords: self-directed learning, learning context, readiness, nursing students.

\section{Introduction}

Nursing graduates today are likely to work in multifaceted healthcare settings where they constantly face challenges stemming from the ongoing social and scientific changes inherent in the healthcare field. Medical science in general and therapeutics in particular, changes rapidly, the life span of useful information is short and there is an information explosion.
Moreover, nurses are prepared as generalists at the undergraduate level; upon employment, they often find themselves feeling like novices in facing the challenges of providing safe and quality care. The responsibility of nursing education is preparing and supporting nurses so that they can successfully adjust and respond to these challenges $^{(1,2)}$.

A key element believed to be important for university graduates to engage 
in continuous learning is their abilities to be self-directed in learning. These self-directed learning abilities are thought to encourage individuals to continue using their personal competencies and outside resources to educate themselves ${ }^{(2)}$. Possessing selfdirected learning qualities is important to the growth and success of the nursing profession, beginning with the education of

nursing students. Lifelong SDL skills are now, more than ever, a necessity for survival especially in the health sciences ${ }^{(3)}$.

Self-directed learning (SDL) is an educational concept that has received increasing attention in recent years particularly in the context of higher education. It has become a focus for nursing education in the past few decades due to the complexity and changes in nursing profession development. Self-directed learning can be defined in terms of the amount of responsibility the learner accepts for his or her own learning. The selfdirected learner takes control and accepts the freedom to learn what they view as important for themselves. The degree of control the learner is willing to take over their own learning will depend on their attitude, abilities and personality characteristics $^{(4)}$.

According to Malcolm Knowles Selfdirected learning is "a process in which individuals take the initiative, with or without the help of others, in diagnosing their learning needs, formulating goals, identifying human and material resources for learning, choosing and implementing appropriate learning strategies, and evaluating learning outcomes ${ }^{(5)}$.

Garrison expanded upon Knowles' definition by presenting a comprehensive model of self-directed learning that includes the dimensions of self-management, selfmonitoring, and motivation. In this context, self-management describes a learner setting goals and managing available resources and support. Self-monitoring encompasses cognitive and metacognitive processes required to construct individual meaning of new concepts by adding to or modifying existing knowledge. Last, motivation refers to the influence of internal and external factors on the believed value to and success of the learner in a learning experience. This final dimension is important at the time the decision is made to enter into a learning activity and to continue in that activity ${ }^{(6)}$.

Self-directed learning readiness is the degree the individual possesses the attitudes, abilities and personality characteristics necessary for self-directed learning. Inherent in this definition are several assumptions about SDL readiness. Firstly, adults are inherently self-directing, i.e. readiness for SDL exists along a continuum and is present in individuals to an extent. Secondly, competencies required for self-direction can be developed to some extent and the best way to learn autonomous behavior is to behave autonomously. Finally, the ability to learn independently in one situation or context can be generalized to other settings $s^{(7,8,9)}$.

Students' self-direction in learning may be influenced by a range of factors, current researches on the development of SDL had focused both on the internal characteristics of the learners as well as the broader context the learners are situated within. Research evidence indicated that certain learning contexts are more effective at promoting self-directed learning and the characteristics used to describe the learning organization are necessary ingredients for SDL to flourish ${ }^{(9,10)}$.

Education programs and experiences which prepare nurses for practice have a vital role to play in ensuring that graduates are self-directed in learning. SDL writers have argued that the development of students' self-direction in learning can be seen as a product of interaction between the learners and their educational experiences $^{(11,12)}$. Many authors noted that students' readiness for being self-directed can be facilitated by introducing appropriate 
learning activities, various teaching approaches and programs such as the learning contract and problem based learning. Additionally, some self-directed writers argued that many elements in the learning context other than the mere implementation of learning activities may be encouraging or discouraging for students' self-direction in learning such as the learning climate which provide opportunities to choose learning topics, the availability of facilitating methods and resources, the use of multifaceted assessment method which focus on the students' participation in questioning and discussion and learning situations where students take control over the task ${ }^{(13,14)}$.

Nursing educators should encourage the development of independent learning skills and enabling nursing students to continue learning independently throughout their professional careers. They play a key role in helping students make a smooth transition from teacher-directed to selfdirected learning. In order to facilitate students' self-directed learning, it is critical to assess their readiness ${ }^{(12,15,16)}$. Teachers must assess the students' readiness for the self-directed learning and methods used to enhance their readiness, establish the boundaries of the students' decisions about their learning and teach about the methodology. Once the students are using the method, the teacher assists them through teaching behaviors that are similar to traditional teaching methods, but that vest more responsibility in the students ${ }^{(1,17,18)}$.

\section{Aims of the Study}

1. Assess community health nursing students' readiness for self-directed learning in Alexandria and Damanhour Nursing Faculties.

2. Identify the relation between nursing students' readiness for self-directed learning and their perception of the learning context.

\section{Research Questions:}

1. Is there a difference between community health nursing students in Alexandria and Damanhour Nursing Faculties in relation to their readiness for self-directed learning?

2. Is there a relation between community health nursing students' readiness for self-directed learning and their perception of learning context?

\section{Materials and Method}

\section{Materials}

Design: Comparative descriptive design was adopted.

Setting: The study was carried out at Faculty of Nursing Alexandria and Damanhour Universities.

Subjects: Using the equal allocation method a convenient sample of 100 undergraduate nursing students registered in the Community Health Nursing Course during the second semester, academic year 20132014 from each of the previously mentioned setting. The total sample size was 200 students.

Tools: In order to fulfill the objective of the study three tools were used:

\section{Tool I: Students' Basic Data Structured Questionnaire}

It was developed by the researcher in order to identify the students' personal and academic data such as age, gender, studying hours, students' academic grades and work experience.

\section{Tool II: Self-directed Learning Readiness} Scale (SDLRS) for Nurses ${ }^{(19)}$

- The Self-directed learning readiness scale (SDLRS) for nurses is a self-report questionnaire developed by Fisher and coworkers at 2001 to determine the extent 
to which individuals perceive themselves as possessing the skills and attitudes which are associated with SDL. It includes 40 itemsdivided into three subscales: self-management (13 items), desire for learning (12 items) and selfcontrol (15 items). The scale is scored on a 5-points likert scale $(1=$ strongly disagree, $2=$ disagree, $3=$ unsure, $4=$ agree and $5=$ strongly agree).

- Total scores greater than 150 indicate readiness for SDL.

\section{Tool III: Course Experience} Questionnaire (CEQ) ${ }^{(20)}$

Course Experience Questionnaire (CEQ) developed by Ramsden at 1991 to assess the students' perception of the learning context in higher education institutions. The scale composed of 40 items with 7 subscales measuring key aspects of learning context: clear goal and standards (5items), good teaching (7items), emphasis on independence ( 9 items), generic skill development (6items), appropriate workload (4items), appropriate assessment (5items) and appropriate resources (4 items). The scale is scored on a 5 -points likert scale $(1=$ strongly disagree, $2=$ disagree, $3=$ unsure, $4=$ agree and $5=$ strongly agree) .

\section{Method}

\section{1- Administrative process:}

Approval of responsible authorities was obtained through official letters from the nursing faculties and after explanation of the purpose of the study.

\section{2- Study tools:}

- Tool (I) was developed by the researcher.

- Tools II\& III were tested for reliability using Cronbach's Alpha Coefficient ( $\mathrm{r}=$ 0.88 for tool II and 0.85 for tool III).

\section{3- Pilot study:}

Pilot study was carried out on 20 students not included in the study sample in order to ensure the clarity of the tools and its comprehension by the target population.

\section{4- Data collection:}

Data were collected through selfadministered questionnaires (tool I, II and III) that were distributed among the undergraduate community health nursing students in Alexandria and Damanhour Nursing Faculties during the second semester, academic year 2013- 2014.

\section{Ethical considerations:}

A written informed consent to participate in the study was obtained from the students. The questionnaire was accompanied with a letter explaining the purpose of research. Anonymity and confidentiality were considered.

\section{Statistical Analysis}

- The collected data were coded and analyzed using PC with the Statistical Package for Social Sciences (SPSS version 20).

- The level of significance selected for this study was $\mathrm{P} \leq 0.05$. It was used as the cut off value for statistical significance.

- Score for each dimension was calculated by summing the scores of each item of the dimensions.

The variables were analyzed using the following statistical measures:

a- Descriptive statistics:

- Range (Minimum, Maximum), Arithmetic mean $(\bar{X})$, Standard deviation (SD) were used as measures of central tendency and dispersion respectively for normally distributed quantitative data.

- Count and percentage were used for describing and summarizing the data.

\section{b- Analytical statistics:}

- Independent samples t-test and One Way ANOVA were used for 
comparing means among the study groups.

\section{Results}

Table (1) reveals that the highest percent of students were females $(75 \%$ in Alexandria\& $61 \%$ in Damanhour). The majority $(80 \%$ and $73 \%)$ of the students in Damanhour and Alexandria Nursing Faculties aged 22 years respectively. Regarding the students' previous academic year performance, nearly half $(45 \% \& 47 \%)$ of students in both faculties were good performers. The table also reveals that less than half (48\%) of students in Alexandria Nursing Faculty spent less than 3 hours/day in studying and doing academic activities and $35 \%$ of them spent from 3-5 hours daily while in Damanhour Faculty of Nursing the majority of the students spent 3-5 hours per day in studying. Lastly, the table shows that more than one third $(36 \%)$ of the students in Alexandria and more than half $(52 \%)$ in Damanhour Nursing Faculty had work experiences.

Table (2) Shows that the total CEQ score of students in Alexandria Nursing Faculty was higher than that of Damanhour as it ranged from 119-171 with a mean of 145.5 \pm 9.6 in Alexandria compared to 89121 with a mean of $105.5 \pm 6.7$ in Damanhour. The table also portrayed that the students' scores were higher among students in Alexandria Nursing Faculty than that of Damanhour in all CEQ domains except appropriate work load since the mean of their scores in such domain were approximately the same $(14 \pm 2.3$ and $14 \pm 2.1$ in Damanhour and Alexandria respectively). Statistical significant differences were found between the students' scores in the two faculties regarding all dimensions except with the appropriate work load.

Table (3) Reveals that the total SDL score of the students in Damanhour Nursing Faculty ranged from 83-122 with a mean of $103.7 \pm 8.3$ compared to $101-184$ with a mean of $143.4 \pm 19.2$ among students in Alexandria Faculty of Nursing. Concerning the score of the students in Damanhour Nursing Faculty regarding the different SDL dimensions it could be observed that their score ranged from 21-39 with a mean of $30.7 \pm 3.2$ in self-management, $22-43$ with a mean of $31.2 \pm 4$. 1in desire for learning and $30-50$ with a mean of $41.8 \pm 4.5$ in selfcontrol while in Alexandria the students' scores were higher in all dimensions since they ranged from 32-61 with a mean of $46.2 \pm 6.2$ in self-management dimension, 26-54 with a mean of $42.7 \pm 6.5$ in desire for learning and 30-50 with a mean of 54.6 \pm 8.0 in self-control dimension. Statistically significant differences were observed between students' scores in Damanhour and Alexandria University regarding the total SDL score and all the SDL subscales.

Table (4) shows that none of the nursing students' in Damanhur scored above 150 which mean that none of them had readiness for self-direction in learning compared to $48 \%$ of the students in Alexandria.

Table (5) indicates that statistically significant relation was found between CEQ score and each of students' academic performance during the previous year $(\mathrm{t}=10.5, \mathrm{p}=0.001)$ and working experience $(\mathrm{t}=4.2, \mathrm{p}=0.001)$ in Alexandria University however, in Damanhour University the significant relation existed between CEQ scores and students' academic performance $(\mathrm{t}=7.9, \mathrm{p}=0.027)$.

Table (6): The table shows the relation between the students' socio-demographic characteristics and their SDL readiness scores. A statistically significant relation was observed between students' SDL scores and each of academic performance and studying hours in both Alexandria and Damanhour Nursing Faculties. Also working experience had a significant impact on the students' SDL readiness scores in Alexandria Faculty of Nursing.

Table (7) demonstrates that all dimensions for CEQ and SDL were significantly positively correlated with correlation coefficient ranged from 0.14 to 
0.86 except for appropriate work load and desire for learning.

\section{Discussion}

In a constantly changing environment, self-directed learning is essential for enabling nursing students to develop independent learning skills, and creating a sense of accountability, responsibility and assertiveness that are essential attributes to the nurse's career ${ }^{(20,21)}$. The practice of nursing demands that its practitioners are self-directed, life-long learners. Some scholars have found that better SDL readiness is related to better academic performance. Hence, there is a reason to believe that SDLR might affect nursing competency $^{(22,23)}$.

Students' self-direction in learning is considered as an outcome of education. Nursing education has a vital role to play in ensuring that graduates can adopt and respond to this need for continuous learning in their professional careers ${ }^{(24,25)}$.

The aims of the study were to assess community health nursing students' readiness for self-directed learning in Alexandria and Damanhour Nursing Faculties and to identify the relationship between nursing students' readiness for selfdirected learning and their perception of the learning context.

Subjects of the study were 200 baccalaureate community health nursing students (100 from Alexandria Faculty of Nursing and 100 from Damanhour Nursing Faculty) completed the questionnaire. Most of the students aged 22 years in both faculties and the majority of them were females. Results will help in providing practical implications that nurse educators may adopt to enhance students' self-directed learning abilities, additionally, they will help in the understanding of the teaching and learning practices and the learning environment which is appropriate for undergraduate nursing students to develop better self-direction in learning.
Results of the current study revealed that there was no significant difference in the mean self-directed learning readiness scores of males and females. Additionally, the students' age had no significant impact on their SDL abilities. This agrees with Chen et al. at 2006 in Taiwan and Roberson and Merriam at 2005 in USA, who found that gender and age were not correlated with self-directed learning. Conversely, McCollinat 2000 in USA reported that gender and age are factors that affect students' self-direction in learning ${ }^{(26,27,28)}$.

Only few studies showed a positive correlation between SDL readiness scores and the students 'academic grades, the results of the current study revealed that SDL scores were higher among the excellent achievers in both Alexandria and Damanhour Nursing Faculties. The same was mentioned by Shaikh R. at 2013 who studied the readiness for self-directed learning in students experiencing two different curricula in one medical school ${ }^{(29)}$.

According to Fisher and coworkers, the developers of the self-directed learning scale, total scores greater than 150 indicate readiness for $\mathrm{SDL}^{(19)}$. Surprisingly none of the students in Damanhour Faculty of Nursing scored more than 150 compared to $48 \%$ of students in Alexandria Nursing Faculty whose score ranged from 101-184. These results could be attributed to the fact that students in most cases prefer the teacher centered methods resulting in resistance to participate in self-directed activities. These percentages were dramatically lower than that reported by ElGilany et al. at 2012 who studied the selfdirected learning readiness and learning styles among Saudi undergraduate and found that $72.7 \%$ scored more than 150 and so, they could be considered as ready for self-directed learning. Additionally, the results contradict those of Abu-Moghli et al. at 2005 and Safavi et al. at 2010 who stated that the majority of Jordanian and Iranian nursing students had high level of SDLR and perceived themselves as independent 
learner. However, these results come in line with that of Lestari and Widjajakusumah at 2009 in Indonesia who indicated that $50 \%$ of the students had low scores for selfdirected learning readiness and that of Shokar et al. at 2002 in USA, who reported that only $11 \%$ of students obtained selfdirected learning readiness scores below the American standard score $\mathrm{e}^{(30,31,32,33,34)}$.

Results of the current study revealed that the students' mean score of readiness for self - direction was higher among Alexandria Faculty students than those of Damanhour Nursing Faculty since the mean scores of self-management, desire for learning and self-control subscales among Damanhour University students were $30.7 \pm 3.2, \quad 31.2 \pm 4.1$ and $41.8 \pm 4.5$; respectively compared to $46.2 \pm 6.2$ for selfmanagement, $42.7 \pm 6.5$ for desire for learning and $54.6 \pm 8$ for self-control among Alexandria University students. The mean total score of SDLR was $103.7 \pm 8.3$ among Damanhour University students compared to $143.4 \pm 19.2$ among Alexandria University students.

This considerable variation between the students in the two universities could be attributed to many factors. First, the credit hours system in Alexandria University which enables the students for making independent choices and decide their own studied subjects through providing a range of elective courses. Secondly, students in Alexandria University may be more involved in learning due to the availability of a range of interactive learning strategies and resources like internet, E-library, ELearning Courses, students' learning contract. Thirdly, methods like the students' portfolio, log book and learning guide help the teacher in guiding the students and providing timely and constructive feedback. fourthly, the academic advice system in Alexandria University make the teacher more approachable and allow for more positive student - teacher interaction which in return improve the students' learning experience and enhance the students' confidence in managing their tasks. Lastly, the utilization of certain evaluation strategies like peer evaluation and selfevaluation methods. These mean scores are lower than those reported from previous studies in other countries. Yuan et al. at 2012 reported that the mean subscales of self-management, desire for learning and self-control were 46.45, 48.84 and 59.43; respectively among Chinese baccalaureate nursing students, while the mean total score of SDLR was 154.72. Additionally, Fisher et al., at 2010 found that the mean subscales of self-management, desire for learning and self-control among Australian undergraduate nursing students were 44.26, 47.31 and 58.98; respectively and the mean total score of SDLR was $150.55^{(8,35)}$.

Although self-directed learning which is a prerequisite for life-long learning can flourish in certain learning environments, many learning environments for adults are still designed around the listen to the teacher-memorize and regurgitate model $^{(36,37,38)}$. Findings drawn from the present study indicated that students' perception of learning context items like good teaching, generic skill development, clear goal and standards, appropriate assessment, emphasis on independence and resource availability had a significant positive effect with a correlation coefficient ranged from 0.14-0.86 on the students' self-directed learning abilities including all the subscales of selfmanagement, desire for learning and selfcontrol. These findings supported by that of nursing studies which revealed that students who perceive their learning environment to consist of good teaching, adequate resources, appropriate assessment and workload report themselves as more likely to adopt self-directed based learning strategies $^{(13,14,37,39)}$.

\section{Conclusion}

Based on the results of the present study it could be concluded that readiness for self-directed learning among Alexandria 
Faculty of Nursing students was higher than those in Damanhur Nursing Faculty and the difference was statistically significant.Students' readiness for selfdirection in learning was significantly affected by their academic performance and studying hours in both faculties. Additionally, the work experience significantly affects the students' readiness for self-directed learning in Alexandria University. Students' perception of learning context items was significantlypositive correlate with their self-directed learning abilities including all the subscales of selfmanagement, desire for learning and selfcontrol.

\section{Recommendations}

In the light of the findings, the following recommendations are suggested:

- Studying factors influencing self-directed learning readiness among undergraduate nursing students is a mandatory.
- Nursing educators should assess and determine the students' readiness for selfdirected learning as not all learners are equally skilled in and/or willing to make decisions about what to learn, and to what depth and breadth.

- Incorporate more independent learning activities and reduce the lecture centered and teacher based strategies.

- Preparing the learning environment to be appropriate for students to develop better self-directed learning abilities and proper preparation for the nursing educators and the students about independent learning strategies that facilitate this type of learning.

- Encourage and assist students who require additional assistance to access strategies to develop skills of self-management, desire for learning and self-control for use in an educational setting. 
Table (1): Distribution of the Students according to their demographic characteristics.

\begin{tabular}{|c|c|c|c|c|}
\hline \multirow{3}{*}{ Characteristics } & \multicolumn{4}{|c|}{ Place } \\
\hline & \multicolumn{2}{|c|}{$\begin{array}{c}\text { Damanhour } \\
(\mathrm{N}=\mathbf{1 0 0})\end{array}$} & \multicolumn{2}{|c|}{$\begin{array}{c}\text { Alexandria } \\
(\mathbf{N}=\mathbf{1 0 0})\end{array}$} \\
\hline & No & $\%$ & No & $\%$ \\
\hline \multicolumn{5}{|l|}{ Gender } \\
\hline - Female & 61 & 61.0 & 75 & 75.0 \\
\hline - Male & 39 & 39.0 & 25 & 25.0 \\
\hline \multicolumn{5}{|l|}{ Age (in years) } \\
\hline - 20 & 3 & 3.0 & 2 & 2.0 \\
\hline - 21 & 3 & 3.0 & 10 & 10.0 \\
\hline - 22 & 80 & 80.0 & 73 & 73.0 \\
\hline - $23+$ & 14 & 14.0 & 15 & 15.0 \\
\hline \multicolumn{5}{|c|}{ Students' previous academic year performance } \\
\hline - Excellent & 4 & 4.0 & 15 & 15.0 \\
\hline - Very Good & 43 & 43.0 & 17 & 17.0 \\
\hline - Good & 45 & 45.0 & 47 & 47.0 \\
\hline - Satisfactory/Failed & 8 & 8.0 & 21 & 21.0 \\
\hline \multicolumn{5}{|l|}{ Studying hours } \\
\hline - $<3 \mathrm{hrs}$ & 13 & 13.0 & 48 & 48.0 \\
\hline - $3-<5$ & 85 & 85.0 & 35 & 35.0 \\
\hline - $5 \mathrm{hrs}$ or more & 2 & 2.0 & 17 & 17.0 \\
\hline \multicolumn{5}{|l|}{ Work experience } \\
\hline - No & 48 & 48.0 & 64 & 64.0 \\
\hline - Yes & 52 & 52.0 & 36 & 36.0 \\
\hline
\end{tabular}


Table (2): Distribution of the students according to Course Experience Questionnaire (CEQ) Domains mean scores.

\begin{tabular}{|c|c|c|c|c|c|}
\hline \multirow{3}{*}{ CEQ domains } & \multicolumn{4}{|c|}{ Mean scores } & \multirow{3}{*}{$\begin{array}{c}\text { t-test } \\
(p \text { value })\end{array}$} \\
\hline & \multicolumn{2}{|c|}{$\begin{array}{c}\text { Damanhour } \\
(\mathrm{N}=100)\end{array}$} & \multicolumn{2}{|c|}{$\begin{array}{c}\text { Alexandria } \\
(\mathrm{N}=100)\end{array}$} & \\
\hline & Min-Max & Mean \pm SD & Min-Max & Mean \pm SD & \\
\hline Good teaching & $15-28$ & $20.4 \pm 2.7$ & $17-33$ & $25.8 \pm 3.4$ & $\begin{array}{c}4.2 \\
(0.001)^{*}\end{array}$ \\
\hline Generic skill development & $12-22$ & $16.8 \pm 2.2$ & $14-27$ & $21 \pm 2.4$ & $\begin{array}{c}3.9 \\
(0.001)^{*}\end{array}$ \\
\hline Clear goal \& standards & $9-17$ & $13 \pm 1.7$ & $13-24$ & $18.8 \pm 2.3$ & $\begin{array}{c}4.0 \\
(0.001)^{*}\end{array}$ \\
\hline Appropriate work load & $10-19$ & $14 \pm 2.3$ & $8-18$ & $14 \pm 2.1$ & $\begin{array}{c}0.74 \\
(0.923) \\
\end{array}$ \\
\hline Appropriate assessment & $9-17$ & $12.4 \pm 2.0$ & $13-22$ & $17.4 \pm 2.1$ & $\begin{array}{c}4.6 \\
(0.001)^{*}\end{array}$ \\
\hline Emphasis on independence & $16-27$ & $21.9 \pm 2.5$ & $24-41$ & $32.9 \pm 3.4$ & $\begin{array}{c}6.9 \\
(0.001)^{*}\end{array}$ \\
\hline Resources availability & $4-12$ & $7.0 \pm 1.5$ & $10-19$ & $15.7 \pm 1.6$ & $\begin{array}{c}5.4 \\
(0.001)^{*}\end{array}$ \\
\hline CEQ total & $89-121$ & $105.5 \pm 6.7$ & $119-171$ & $145.5 \pm 9.6$ & $\begin{array}{c}7.5 \\
(0.001)^{*}\end{array}$ \\
\hline
\end{tabular}

Table (3): Distribution of the students according to their self-directed learning readiness dimensions mean scores.

\begin{tabular}{|c|c|c|c|c|c|}
\hline \multirow{3}{*}{ SDL domains } & \multicolumn{4}{|c|}{ Mean scores } & \multirow{3}{*}{$\begin{array}{c}\text { t-test } \\
\text { (p value) }\end{array}$} \\
\hline & \multicolumn{2}{|c|}{$\begin{array}{c}\text { Damanhour } \\
(\mathrm{N}=100)\end{array}$} & \multicolumn{2}{|c|}{$\begin{array}{c}\text { Alexandria } \\
(\mathbf{N}=100)\end{array}$} & \\
\hline & Min-Max & Mean \pm SD & Min-Max & Mean \pm SD & \\
\hline Self-management & $21-39$ & $30.7 \pm 3.2$ & $32-61$ & $46.2 \pm 6.2$ & $\begin{array}{c}5.1 \\
(0.001)^{*}\end{array}$ \\
\hline Desire for learning & $22-43$ & $31.2 \pm 4.1$ & $26-54$ & $42.7 \pm 6.5$ & $\begin{array}{c}7.8 \\
(0.001)^{*}\end{array}$ \\
\hline Self-control & $30-50$ & $41.8 \pm 4.5$ & $39-70$ & $54.6 \pm 8.0$ & $\begin{array}{c}7.6 \\
(0.001)^{*}\end{array}$ \\
\hline SDL total & $83-122$ & $103.7 \pm 8.3$ & $101-184$ & $143.4 \pm 19.2$ & $\begin{array}{c}8.1 \\
(0.001)^{*}\end{array}$ \\
\hline
\end{tabular}

P: independent samples t-test

$* \mathrm{P}<0.05$ (significant) 
Table (4): Distribution of the Students According to their Self-Directed Learning Readiness Level.

\begin{tabular}{|c|c|c|c|c|c|}
\hline \multirow{3}{*}{ The Nursing Faculty } & \multicolumn{4}{|c|}{$\begin{array}{c}\text { Self-Directed Learning Readiness } \\
\text { Level }\end{array}$} & \multirow{3}{*}{$\mathbf{x}^{2} \mathbf{P}$} \\
\hline & \multicolumn{2}{|c|}{ Low $(<150)$} & \multicolumn{2}{|c|}{ High (>150) } & \\
\hline & No & $\%$ & No & $\%$ & \\
\hline - Damanhour & 100 & 100.0 & 0 & 0.0 & \multirow{2}{*}{$0.001 *$} \\
\hline - Alexandria & 52 & 52.0 & 48 & 48.0 & \\
\hline
\end{tabular}

Table (5): Relation between students' socio-demographic characteristics their perception of learning context mean scores in Alexandria and Damanhour Nursing Faculties.

\begin{tabular}{|c|c|c|c|c|}
\hline \multirow{3}{*}{$\begin{array}{l}\text { Socio-demographic } \\
\text { characteristics }\end{array}$} & \multicolumn{4}{|c|}{ Mean Score } \\
\hline & \multirow{2}{*}{$\begin{array}{c}\text { Damanhour } \\
(\mathrm{N}=100) \\
\text { Mean } \pm \text { SD }\end{array}$} & \multirow{2}{*}{$\begin{array}{l}\text { Test of } \\
\text { significance } \\
\text { (P value) }\end{array}$} & \multirow{2}{*}{$\begin{array}{c}\begin{array}{c}\text { Alexandria } \\
(\mathrm{N}=100)\end{array} \\
\text { Mean } \pm \text { SD }\end{array}$} & \multirow{2}{*}{$\begin{array}{c}\text { Test of } \\
\text { significance } \\
\text { (P value) }\end{array}$} \\
\hline & & & & \\
\hline \begin{tabular}{cl}
\multicolumn{2}{l}{ Gender } \\
- & Female \\
- & Male \\
\end{tabular} & $\begin{array}{l}105.9 \pm 6.5 \\
104.9 \pm 7.0\end{array}$ & $\begin{array}{c}1.1 \\
(0.477) \#\end{array}$ & $\begin{array}{l}146.6 \pm 9.6 \\
142.4 \pm 9.1 \\
\end{array}$ & $\begin{array}{c}1.74 \\
(0.063) \#\end{array}$ \\
\hline 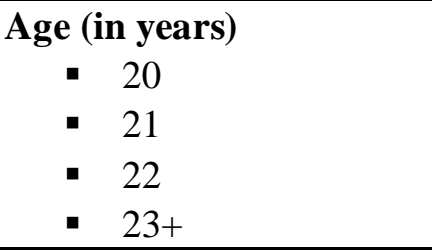 & $\begin{array}{l}107.0 \pm 3.0 \\
99.3 \pm 10.5 \\
106.3 \pm 6.6 \\
101.5 \pm 4.6 \\
\end{array}$ & $\begin{array}{c}3.2 \\
(0.068)\end{array}$ & $\begin{array}{c}146.5 \pm 7.8 \\
148.9 \pm 6.4 \\
145.4 \pm 9.8 \\
139.4 \pm 12.8\end{array}$ & $\begin{array}{c}4.3 \\
(0.368)\end{array}$ \\
\hline $\begin{array}{l}\text { Students' previous acader } \\
\text { - Excellent } \\
\text { - Very Good } \\
\text { - Good } \\
\text { - Satisfactory/Failed }\end{array}$ & $\begin{array}{c}\text { ar performanc } \\
106.5 \pm 6.6 \\
105.9 \pm 5.9 \\
98 \pm 8.3 \\
101.6 \pm 8.0 \\
\end{array}$ & $\begin{array}{c}7.9 \\
(0.027)^{*}\end{array}$ & $\begin{array}{l}151.4 \pm 7.7 \\
140.2 \pm 5.0 \\
142.1 \pm 9.9 \\
139.2 \pm 9.0\end{array}$ & $\begin{array}{c}10.5 \\
(0.001)^{*}\end{array}$ \\
\hline $\begin{array}{cl}\text { Studying hours } \\
\qquad & <3 \\
\cdot & 3-<5 \\
\cdot & 5+ \\
\end{array}$ & $\begin{array}{c}102.3 \pm 5.4 \\
106.1 \pm 6.1 \\
95.3 .0 \pm 0.0 \\
\end{array}$ & $\begin{array}{c}5.9 \\
(0.185)\end{array}$ & $\begin{array}{c}142.7 \pm 8.1 \\
148.3 \pm 11.2 \\
142.3 \pm 8.2 \\
\end{array}$ & $\begin{array}{c}5.4 \\
(0.189)\end{array}$ \\
\hline $\begin{array}{c}\text { Work experience } \\
\text { - No } \\
\text { - Yes }\end{array}$ & $\begin{array}{l}105.5 \pm 5.8 \\
105.6 \pm 7.4\end{array}$ & $\begin{array}{c}0.84 \\
(0.953) \#\end{array}$ & $\begin{array}{l}148.3 \pm 8.8 \\
140.6 \pm 9.2 \\
\end{array}$ & $\begin{array}{c}4.2 \\
(<0.001)^{* \#}\end{array}$ \\
\hline
\end{tabular}


Table (6): Relation between students' socio-demographic characteristics and their selfdirected learning readiness mean scores in Alexandria and Damanhur Nursing Faculties.

\begin{tabular}{|c|c|c|c|c|}
\hline \multirow{3}{*}{$\begin{array}{l}\text { Socio demographic } \\
\text { characteristics }\end{array}$} & \multicolumn{4}{|c|}{ Mean self-directed learning readiness scores } \\
\hline & Damanhour & & Alexandria & \\
\hline & Mean \pm SD & $\begin{array}{l}\text { Significance } \\
\text { (P value) }\end{array}$ & Mean \pm SD & $\begin{array}{c}\text { Significance } \\
\text { (P value) }\end{array}$ \\
\hline \begin{tabular}{cl}
\multicolumn{2}{l}{ Gender } \\
- & Female \\
- & Male \\
\end{tabular} & $\begin{array}{l}104.4 \pm 7.7 \\
102.6 \pm 9.1 \\
\end{array}$ & $\begin{array}{c}1.0 \\
(0.313) \#\end{array}$ & $\begin{array}{c}145 \pm 20.0 \\
138.5 \pm 16.1 \\
\end{array}$ & $\begin{array}{c}1.4 \\
(0.142) \#\end{array}$ \\
\hline $\begin{array}{c}\text { Age (in years) } \\
\text { - } 20 \\
\text { - } 21 \\
\text { - } 22 \\
\text { - } 23+ \\
\end{array}$ & $\begin{array}{c}101.3 \pm 6.4 \\
92.3 \pm 8.6 \\
104.7 \pm 7.7 \\
100.7 \pm 10.0 \\
\end{array}$ & $\begin{array}{c}6.6 \\
(0.061)\end{array}$ & $\begin{array}{c}157.5 \pm 9.2 \\
138.4 \pm 13.0 \\
143.9 \pm 20.6 \\
140.9 \pm 17.1 \\
\end{array}$ & $\begin{array}{c}3.6 \\
(0.748)\end{array}$ \\
\hline $\begin{array}{l}\text { Students' previous acade } \\
\text { - Excellent } \\
\text { - Very Good } \\
\text { - Good } \\
\text { - Satisfactory/Failed }\end{array}$ & $\begin{array}{c}\text { performance } \\
106.1 \pm 7.4 \\
104.3 \pm 6.9 \\
93.5 \pm 6.5 \\
91.9 \pm 8.0 \\
\end{array}$ & $\begin{array}{c}12.7 \\
(0.001)^{*}\end{array}$ & $\begin{array}{l}155.1 \pm 13.0 \\
135.7 \pm 15.0 \\
133.7 \pm 17.9 \\
130.5 \pm 20.4 \\
\end{array}$ & $\begin{array}{c}11.8 \\
(0.001)^{*}\end{array}$ \\
\hline $\begin{array}{cl}\text { Studying hours } \\
\text {. } & <3 \\
\text {. } & 3-<5 \\
\text {. } & 5+ \\
\end{array}$ & $\begin{array}{c}93.1 \pm 5.9 \\
105.2 \pm 6.9 \\
92.0 \pm 0.0 \\
\end{array}$ & $\begin{array}{c}10.1 \\
(0.001)^{*}\end{array}$ & $\begin{array}{l}136.5 \pm 16.6 \\
150.6 \pm 19.4 \\
129.3 \pm 12.7 \\
\end{array}$ & $9.4(0.005)^{*}$ \\
\hline $\begin{array}{c}\text { Work experience } \\
\text { - } \mathrm{No} \\
\text { - } \mathrm{Yes} \\
\end{array}$ & $\begin{array}{l}103.4 \pm 7.9 \\
103.9 \pm 8.7 \\
\end{array}$ & $\begin{array}{c}0.57 \\
(0.752) \#\end{array}$ & $\begin{array}{l}150.7 \pm 17.1 \\
130.4 \pm 15.7\end{array}$ & $\begin{array}{c}5.7 \\
(<0.001)^{* \#}\end{array}$ \\
\hline
\end{tabular}

P: One Way ANOVA 
Table (7): Correlation between Self - Directed Learning Readiness Domains and Students Perception of Learning Context (CEQ) Dimensions.

\begin{tabular}{|c|c|c|c|c|}
\hline Items & $\begin{array}{c}\text { Self- } \\
\text { management }\end{array}$ & $\begin{array}{c}\text { Desire for } \\
\text { learning }\end{array}$ & Self-control & SDL total \\
\hline Good. Teaching & $0.75^{*}$ & $0.64^{*}$ & $0.68^{*}$ & $0.74^{*}$ \\
\hline Generic skill development & $0.65^{*}$ & $0.57^{*}$ & $0.60^{*}$ & $0.64^{*}$ \\
\hline Clear goal \& standards & $0.83^{*}$ & $0.71^{*}$ & $0.71^{*}$ & $0.80^{*}$ \\
\hline Appropriate work load & $0.15^{*}$ & 0.07 & $0.17^{*}$ & $0.14^{*}$ \\
\hline Appropriate assessment & $0.61^{*}$ & $0.46^{*}$ & $0.47^{*}$ & $0.55^{*}$ \\
\hline Emphasis on independence & $0.86^{*}$ & $0.77^{*}$ & $0.74^{*}$ & $0.84^{*}$ \\
\hline Resources availability & $0.79^{*}$ & $0.68^{*}$ & $0.68^{*}$ & $0.76^{*}$ \\
\hline CEQ.total & $0.89^{*}$ & $0.76^{*}$ & $0.78^{*}$ & $0.86^{*}$ \\
\hline \hline
\end{tabular}

* Significant correlation co-efficient Interpretation of $\mathbf{r}$ :

Weak (0.1-0.24) 


\section{References}

1. Lucy M, Guglielmino. Why self-directed learning? International Journal of SelfDirected Learning 2008; 5(1):1-14.

2. Koehler M. \& Mishra P. Handbook of Technological Pedagogical Content Knowledge for Educators.2008; (pp. 128).

3. Bastable S. Nurse as Educator: Principles of Teaching and Learning for Nursing Practice. 3rd ed. Boston: Jones and Barlett Learning; LLC, 2008.

4. Anema MG, McCoy J. Competencybased nursing education. New York: Springer; 2009.

5. Knowles M. Self-directed learning: A guide for learners and teachers. New York: NY: Association Press; 1975.

6. Garrison D. Self-directed learning: Toward a comprehensive model. Adult Education Quarterly 1997; 48(1), 18-33.

7. Candy P. Linking thinking. Self-directed learning in the digital age. Canberra: Australian Government, Department of Education, Science and Training 2004.

8. Fisher M., King J. The self-directed learning readiness scale for nursing education revisited: a confirmatory factor analysis. Nurse Education Today 2010; 30 (1): 44-48.

9. Cheng S., Kuo C., Lin K., Lee-Hsieh J. Development and preliminary testing of a self-rating instrument to measure selfdirected learning ability of nursing students. International Journal of Nursing Studies 2010; 47 (9):11521158.

10. O'shea, E. Self-directed learning in nursing education: A review of literature. Journal of advanced nursing 2003; 43(1), 62-70.

11. Greene J. Azevedo R. The measurement of learners' self-regulated cognitive and metacognitive processes while using computer-based learning environments.
Educational Psychologist 2010; 45(4): 203-209.

12. Stockdale S. Brockett R. Development of the PRO-SDL: A measure of self direction in learning based on the personal responsibility orientation model, Adult Education Quarterly 2011; 61 (2): 161-80.

13. Diseth A., Pallesen A., Larsen S., Course experience: approaches to learning and academic achievement. Education and training 2006; 48(2/3), 156-168.

14. Lizzo A., Wilson K, Simons R. University Students' perception of the learning environment and academic outcomes: implications for theory and practice. Studies in higher education 2005; 27(1), 27-53.

15. Chou P. Chen W. Exploratory study of the relationship between self-directed learning and academic performance in a web-based learning environment. Online Journal of Distance Learning Administration 2008; 11(1).

16. Regan J. Motivating students towards self-directed learning. Nurse education today $2012 ; 23(8), 593-599$. Available at:

DOI:

http://dx.doi.org/10.1016/j.nedt.2012.02. $\underline{006 .}$.

17. Klunklin A., Viseskul N., Sripusanapan A., \& Turale S. Readiness for selfdirected learning among nursing students in Thailand. Nursing and Sciences 2010; 12(2), 177-181.

18. Yuan H., Williams B., Fang J. \& Pang D. Chinese baccalaureate nursing students 'readiness for self-directed learning. Nurse Education Today 2012; 32(4): 427431. Available at: doi: 10.1016/j.nedt.2011.03.005.

19. Fisher M., King J., Tague G. Development of a self-directed learning readiness scale for nursing education. 
Nurse Education Today 2001; 21: 516525.

20. Ramsden P. Using the CEQ. Paper presented at the Course Experience Questionnaire Symposium 1991.

21. Bastable S. Nurse as Educator: Principles of Teaching and Learning for Nursing Practice, 3rd ed. Jones and Barlett Learning, LLC, Boston 2008.

22. Levett-Jones T. Self-directed learning: implications and limitations for undergraduate nursing education. Nurse Education Today2005; 25 (5):363-368.

23. Reio T. Prior knowledge, self-directed learning readiness, and curiosity: antecedents to classroom learning performance. Int J Self-Directed Learn $2004 ; 1: 18$

24. Yuan HB, Williams BA, Fang JB, Pang D. Chinese baccalaureate nursing students' readiness for self-directed learning. Nurse Educ Today 2012; 32:427e31.

25. Wang W, Cheng Y, Yuan HB, Bai JJ, Wu JQ, Zhang Y. The student nurses' self-directed learning readiness and its influential factors. Chin J Nurs 2010; 45:335.

26. Chen Y, Wang C., Lin H. Explore the relationships among demography, personality traits and self-directed learning. Journal of Human Resources and Adult Learning 2006, 141-150. Available at:

http://www.hraljournal.com/Page/19\%20 Yu-Fen\%20Chen.pdf. Accessed at: February 1, 2014.

27. Roberson D., Merriam S. The selfdirected learning process of older adults. Adult Education Quarterly2005; 55 (4): 269-287.

28. McCollin, E. Faculty and student perceptions of teaching style: do teaching styles differ for traditional and nontraditional students? Presented at: Annual Conference of Mid-South Educational Research Association.2000 (Bowing Green, KY, November 15-17). Available at: http://www.eric.ed.gov/PDFS/ED44713 9.pdf. Accessed at: February1, 2014.

29. Shaikh R. Comparison of readiness for self-directed learning in students experiencing two different curricula in one medical school, Gulf medical journal 2013; 2(1): 27-31.

30. El-Gilany A, Abusaad F. Self-directed learning readiness and learning styles among Saudi undergraduate nursing students, Nurse Educ. Today 2012, available at: doi:10.1016/j.nedt.2012.05.003.

31. Abu-Moghli F., Khalaf I., Halabi J., Wardam L. Jordanian baccalaureate nursing students' perception of their learning styles. International Nursing Review 2005; 52, 39-45.

32. Safavi M., Schooshtari S., Mahmoodi M., Yarmohammadian M. Self-directed learning readiness and learning styles among nursing students of Isfahan University of Medical Sciences. Iranian Journal of Medical Education 2010; 10 (1), 27-35.

33. Lestari E., Widjajakusumah D. Students' self-directed learning readiness, perception toward student-centered learning and predisposition towards student centered behavior. South East Asian Journal of Medical Education 2009; 3 (1), 52-56.

34. Shokar G., Romero C., Bulik R. Selfdirected learning: looking at outcomes with medical students. Family Medicine 2002; 34 (3), 197-200.

35. Yuan H., Williams B., Fang J., Pang D. Chinese baccalaureate nursing students readiness for self-directed learning. 
Nurse Education Today 2012; 32 (4), 427-431.

36. Levett-Jones T. Self-directed learning: implications and limitations for undergraduate nursing education. Nurse Education Today 2005; 25 (5), 363-368.

37. Greveson GC, Spencer JA. Self-directed learning: the importance of concepts and contexts. Medical education. 2005; 39: 348-49.
38. Wood DF. ABC of learning and teaching in medicine: Problem Based Learning. BMJ. 2003; 326: 328-30.

39. Gurjeet SS, Navkiran KS, Cecilia MR, Robert JB. Self-directed Learning: Looking outcomes with Medical Students. Fam Med. 2002; 34(3):197200. 